\title{
A MONOGRAPH OF Acaulospora spp.(VAM FUNGI) IN SUNFLOWER RHIZOSPHERE IN HARYANA, INDIA
}

\author{
Sharma, S., Parkash, V., Kaushish, S. and Aggarwal, A.
}

Botany Department, Kurukshetra University, Kurukshetra-136119,

Haryana, India

Received: August 20, 2007

Accepted: May 22, 2009

\author{
SUMMARY
}

\begin{abstract}
A total of seven Acaulospora species (Acaulospora laevis, A. lacunose, A. rehmii, A. foveata, A. gerdemanniii, A. bireticulata, A. scrobiculata) isolated from sunflower rhizosphere are described and illustrated. A key to species of Acaulospora genus has also been prepared on the basis of their morphological characters. Spores of these species have been identified by morphological characters such as hyphal attachment if any, spore ornamentation, wall layers and spore color and size.
\end{abstract}

Key words: sunflower rhizosphere, Acaulospora spp., vesicular arbuscular mycorrhizal fungi (VAMF)

\section{INTRODUCTION}

VAMF (vesicular arbuscular mycorrhizal fungi) develop a major network of microscopic filaments in the soil. When filaments of these fungi come in contact with a young root, they thread their way between the cortical cells and quickly propagate, forming intracellular arbuscules and, in some cases, intercellular vesicles. These arbuscular fungi are so called because of the tree-like structures that grow into roots. Spores grow in the soil as well as into the roots. They act as reserve and propagation organs and as a reference structure for species identification. Thus far we have no serious clue as to the sexuality of AMF. Their association with the zygomycetes is based on the similarity of their spores to the spores of other known representatives of this class. The VAMF belong to a very old category of fungi, the zygomycetes, and have been recently regrouped in a single order, the Glomales (Morton and Benny, 1990), which include all species capable of living in symbiosis with plants. The bulk of known species belongs to the family Glomaceae (Pirozynski and Dalpe, 1989), which includes the genera Glomus and Sclerocystis. The VAMF consist actually of approximately 207 species belonging to 3 families and 8

* Corresponding author: e-mail: aggarwal_vibha@rediffmail.com 
genera and they have a worldwide distribution. Most of the known species have been described over the last two decades, which indicates the increased interest in these organisms and also the difficulty inherent in their taxonomic treatment. In fact, the greatest difficulty is that the entire taxonomy of these organisms is currently based on the morphological characters of their spores. They are single-celled structures, of generally globoid shape, with thick walls made up of several layers of different textures, connected to the filamentous network by a suspensor hypha of varied morphology. Since the morphological characters are reduced and often variable depending on the maturity of the spores studied, ultrastructural studies serve to support observations made previously in optic microscopy. In addition, although still exploratory, molecular approaches can be used to detect, with the help of specific probes and only for some species, the qualitative and quantitative presence of a fungus directly in its substrate. Therefore, an approach was made to explore the Acaulospora spp. colonizing the sunflower rhizosphere in Haryana state of India.

\section{MATERIALS AND METHODS}

An extensive investigation of the genus Acaulospora in the rhizosphere of sunflower from Haryana, India, has been conducted to collect various species from various areas using wet sieving and decanting technique (Gerdemann and Nicolson, 1963). Spores were multiplied in the greenhouse with maize as host plant. For taxonomic purpose, spores were mounted in PVLG medium.

\section{RESULTS AND DISCUSSION}

Seven species of Acaulospora were isolated and identified using manuals of Trappe (1982), Walker (1983), Morton and Benny (1990), Schenck and Perez (1990) and Mukerji (1996).

\section{Acaulospora Gerd. \& Trappe emend. Berch.}

In Greek, acaulospora means "spores without a stem" or sessile spores. In this genus, spores are borne laterally from the neck of a pre-differentiated "sporiferous saccule". The genus includes spores which are formed singly and ectocarpically in the soil. Spore formation begins with the formation of large, thin-walled vesicles at the end of wide hyphae. The contents of this vesicle then migrate back in to the hyphae and enter the sessile resting spores which form on the side of the parent hypha. These resting spores are having two or more wall layers and in some cases complex ornamentation occurs on the outer surface. The spore germination is through peripheral wall compartments generally.

Sometimes spores are formed laterally on the neck of a small thin-walled saccule called a mother spore or vesicle or sporogenous saccule. At maturity, the spore does not show subtending hyphae. Spores are globose to ellipsoid ranging from 40- 
$400 \mu \mathrm{m}$ in diameter. The surface of the spore wall may be ornamented with pits, projections, spines or reticulations.

\section{Acaulospora laevis Gerd. \& Trappe}

Spores are generally honey colored, sessile in nature, sometimes spores show expressions of hyphal attachment known as eccetrix, walls thick at eccetrix point, wall layer smooth with homogenous matrix, 200-400 $\mu \mathrm{m}$ in diameter, ellipsoid to egg-shaped generally (Figure 1, C-D).

\section{Acaulospora foveata Trappe \& Janos}

Spores are generally brown to black in color, $>150 \mu \mathrm{m}$ in diameter, sporocarps unknown, azygospores formed singly in soil, spores globose or ellipsoid, $>300 \mu \mathrm{m}$ in diameter, yellowish brown to light reddish brown when young, becoming reddish brown at maturity, spore surface uniformly pitted with round to oblong or occasionally irregular depressions, outer spore wall reddish brown to brown, 11-15 $\mu \mathrm{m}$ thick with an adherent but separable hyaline inner layer, $3 \mu \mathrm{m}$ thick, spore content of small hyaline guttules (Figure 1, A-B).

\section{Acaulospora rehmii Siv. \& Toro}

Spores reddish brown in color, $>100 \mu \mathrm{m}$ in diameter, sessile in nature, almost round and spherical, spore wall not much distinct, ornamented with labyrinth-form channels or network on the outer surface of wall layer (Figure 1, M-N).

\section{Acaulospora scrobiculata Trappe}

Sporocarps unknown, azygospores form singly in soil, spores globose to broadly ellipsoid, 200-250 $\mu \mathrm{m}$ light brown at maturity, sometimes consisting of layers, outer rigid hyaline to light greenish yellow, 3-6 $\mu \mathrm{m}$ thick followed by adhering but separable, smooth surface of outermost layer ornamented with profuse minute pores (Figure 1, G-H).

\section{Acaulospora bireticulata Rothwell \& Trappe}

Azygospores formed singly in soil, sessile, globose to sub-globose, vesicles 100$150 \mu \mathrm{m}$ diameter, spores globose, sub-hyaline when young, spore surface ornamented with a polygonal reticulum network, spore wall three-layered, the outer layer grayish brown, the inner layers hyaline (Figure 1, I-J).

\section{Acaulospora lacunose Morton}

Spores formed singly in soil, reddish-yellow in color, globose to sub-globose, 130-180 $\mu \mathrm{m}$ in diameter, spore wall structure consists of 5 walls in three groups (A, $\mathrm{B}, \mathrm{C})$. This is why spores look like rings, group A, a laminated reddish brown wall approximately 1-1.6 $\mu \mathrm{m}$ thick, outer and inner surfaces of this wall ornamented with irregular pits, group B two rigid hyaline walls (walls 2 and 3), each 0.5-1.5 $\mu \mathrm{m}$ thick, group $\mathrm{C}$ two hyaline walls (walls 4 and 5) $0.5 \mu \mathrm{m}$ thick (Figure 1, E-F). 

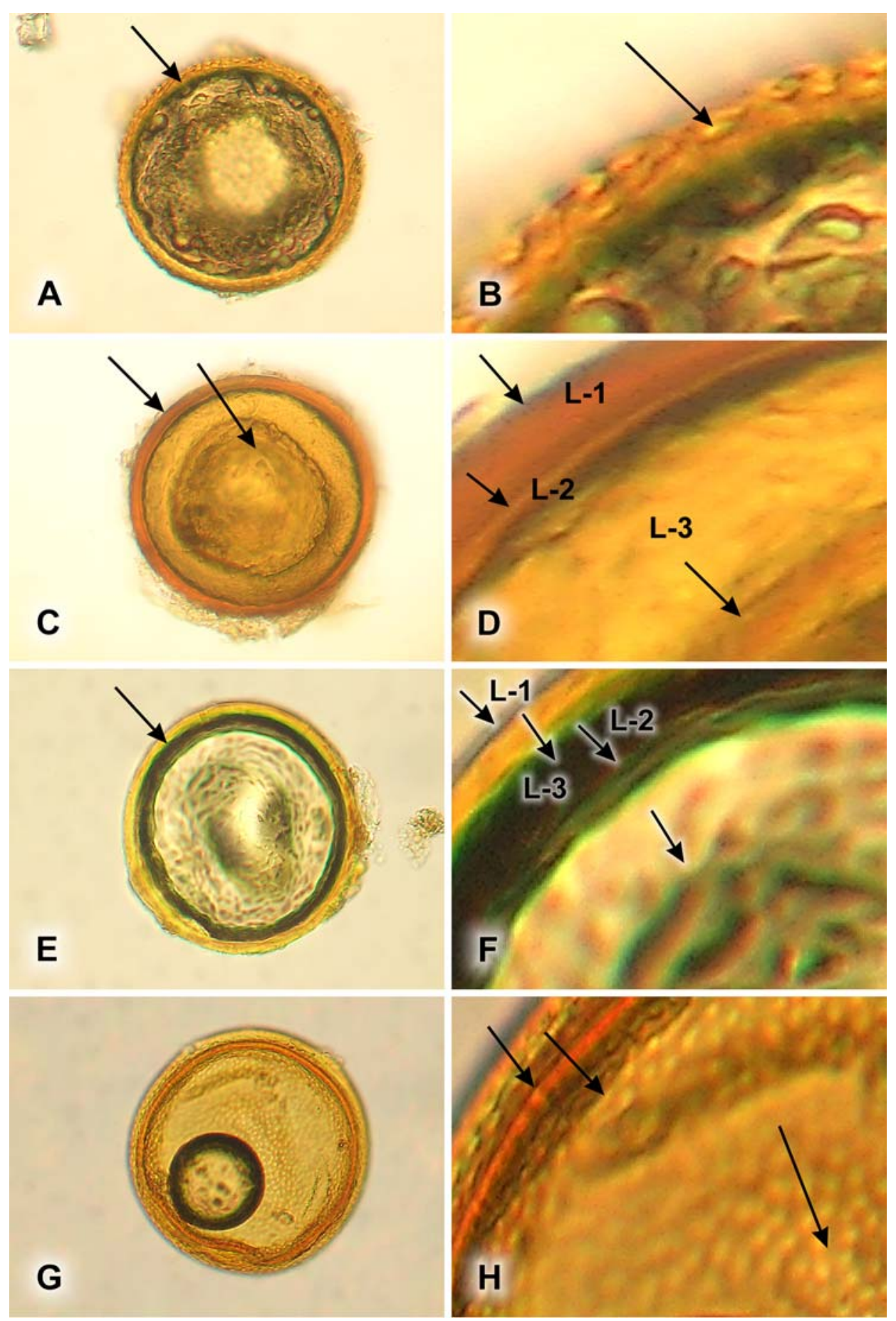

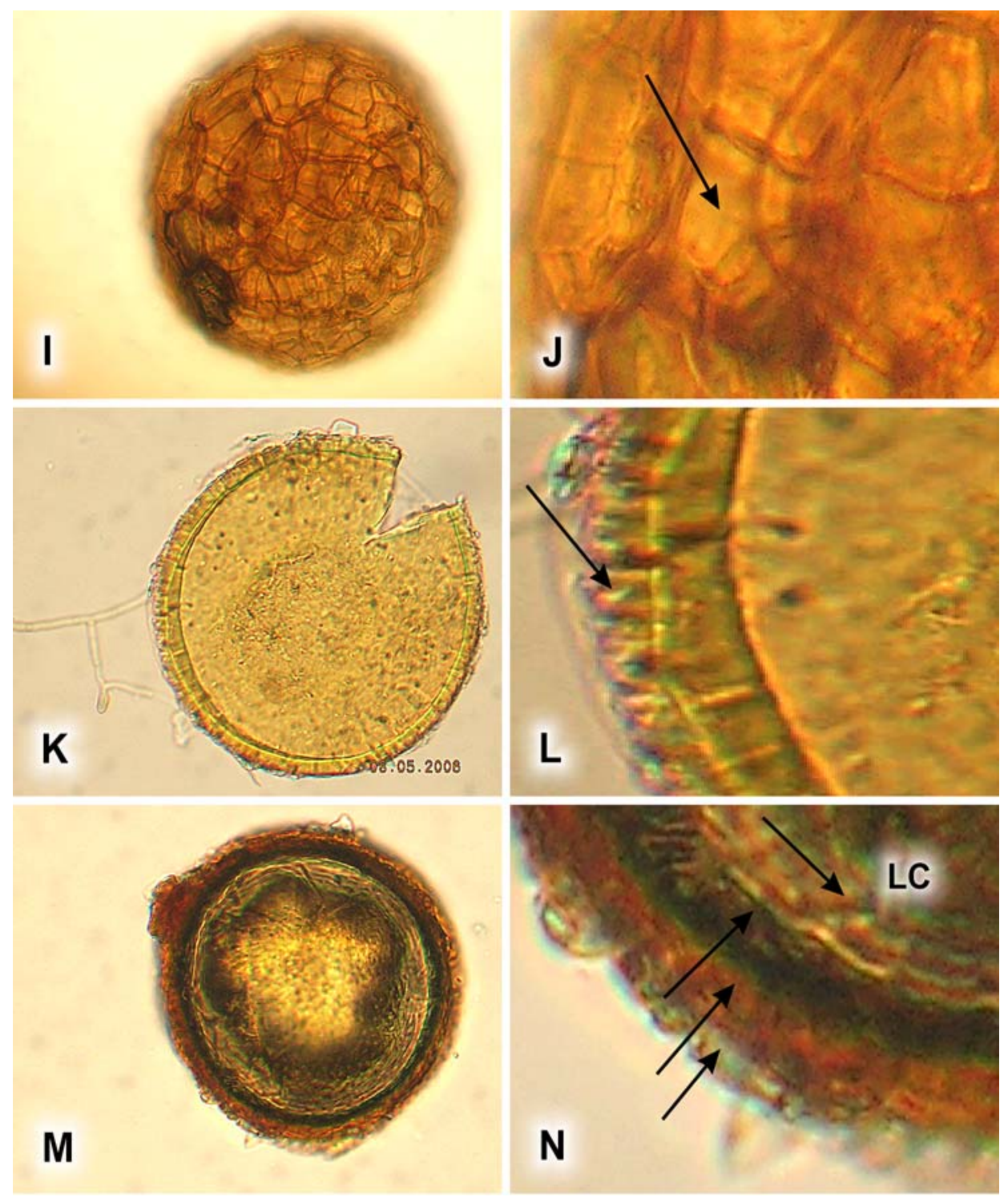

Figure 1:
A. Acaulospora foveata
C. Acaulospora laevis
E. Acaulospora lacunose
G. Acaulospora scrobiculata
I. Acaulospora bireticulata
K. Acaulospora gerdemannii
M. Acaulospora rehmii

B. Outer wall layer with saucer-shaped pits

D. With homogenous smooth wall layers

F. Different wall layers with concentric rings

$H$. Wall layers and pits with pores

$J$. With polygonal reticulation on outer surface

L. With alveolate wall layer

$N$. With different wall layers and innermost labyrinthine channels (LC) 


\section{Acaulospora gerdemannii Scenck \& Nicolson}

Spores formed singly in the soil, yellowish brown in color, round to spherical, 100-200 $\mu \mathrm{m}$ in diameter, surface of outermost wall layer ornamented with cerebriform folds up to $>12 \mu \mathrm{m}$ in breadth. Spore contents at maturity granulated (Figure $1, \mathrm{~K}-\mathrm{L})$.

Key to the species Acaulospora

1 Azygospores with grayish brown, globose to subglobose vesicle, surface $\quad$ A. bireticulata ornamented with a polygonal reticulum

2 Spores with pitted surface. Pits with round to oblong depressions with round A. foveata bottoms, separated by ridges, $1-12 \mu \mathrm{m}$ broad

3 Outer and inner surfaces of the wall possess irregular pits and a number of A. lacunose scattered pits with cone-shaped edges, many wall layers in round rings

4 Spores reddish brown in color, $>100 \mu \mathrm{m}$ in diameter, almost sessile, round A. rehmii and spherical, spore wall not much distinct, ornamented with labyrinthine channels or network on the outer surface

5 Spores generally honey colored, sessile in nature, walls thick at eccetrix point, $A$. laevis wall layer smooth with homogenous matrix, 200-400 $\mu \mathrm{m}$ in diameter, ellipsoid to egg shaped generally

6 Spores with light brown, surface evenly pitted with depressions/profuse minute A. scrobiculata pores, consisting of wall layers when ruptured

7 Spores red to brown, round to spherical, $100-200 \mu \mathrm{m}$ in diameter, surface of A. gerdemannii outermost wall layer ornamented with cerebriform folds up to $12 \mu \mathrm{m}$ in breadth

\section{ACKNOWLEDGEMENTS}

The authors Sapana Sharma and Vipin Parkash are thankful to Kurukshetra University, Kurukshetra, and CSIR, New Delhi, India, for financial assistance, respectively.

\section{REFERENCES}

Gerdemann, J.W. and Nicolson, Y.H., 1963. Spores of mycorrhizae Endogone species extracted from soil by wet sieving and decanting. Trans. Br. Mycol. Soc. 46: 235-244.

Morton, J.B. and Benny, G.L., 1990. Revised classification of arbuscular mycorrhizal fungi (Zygomycetes): New order, Glomales, two new sub-orders, Glomineae and Gigasporine$a e$, and two new families, Acaulosporaceae and Gigasporaceae, with emendation of Glomoceae. Mycotaxon 37: 471-491.

Mukerji, K.G., 1996. Taxonomy of endomycorrhizal fungi. In: Mukerji, K.G., Mathur, B., Chamola, B.P. and Chitralekha, P. (Eds.), Advances in Botany. APH Pub. Corp. New Delhi, pp. 211-221.

Pirozynski, K.A. and Dalpe, Y.,1989. The geological history of the Glomaceae with particular reference to mycorrhizal symbiosis. Symbiosis 7: 1-36.

Schenck, N.C. and Perez, Y., 1990. Manual for the identification of VA mycorrhizal (VAM) fungi. Univ. of Florida Press, Florida, USA. pp. 241.

Walker, C., 1983. Taxonomic concepts in the Endogonaceae spore wall characteristics in species description. Mycotaxon 18: 443-445. 


\title{
MONOGRAFÍA SOBRE Acaulospora spp. (VAM FUNGI) EN LA RIZÓSFERA DEL GIRASOL EN HARYANA, INDIA
}

\author{
RESUMEN
}

Se describieron e ilustraron siete especies de Acaulospora (Acaulospora laevis, A. lacunose, A. rehmii, A. foveata, A. gerdemannii, A. bireticulata, A. scrobiculata) aisladas de la rizósfera del girasol. Se preparó una clave de las especies del género Acaulospora sobre la base de caracteres morfológicos. Se identificaron las esporas de estas especies sobre la base de caracteres morfológicos como adherencia hifal si la hubiera, ornamentación de las esporas, capas de las paredes celulares y color y tamaño de esporas.

\section{MONOGRAPHIE SUR Acaulospora spp. (CHAMPIGNONS VAM) DANS LA RHIZOSPHÈRE DU TOURNESOL À HARYANA, INDE}

\section{RÉSUMÉ}

Un total de sept espèces du genre Acaulospora (Acaulospora laevis, A. lacunose, A. rehmii, A. foveata, A. gerdemanniii, A. bireticulata, A. scrobiculata) isolées à partir de la rhizosphère du tournesol sont décrites et illustrées. Une clef de détermination de l'espèce au sein du genre Acaulospora est préparée sur la base des caractères morphologiques. Les spores de ces espèces ont été identifiées sur des caractères morphologiques tels que l'attachement des hyphes le cas échant, l'ornementation des spores, la paroi, la couleur et la taille des spores. 
